\title{
Spatio-Temporal Study on Supply and Demand Matching of Ecosystem Water Yield Service - A Case Study of Wei River Basin
}

\author{
Yuanyuan Li, Shunbo Yao*, Yuanjie Deng, Lei Jia, Mengyang Hou, Zhiwen Gong \\ College of Economics and Management, Northwest Agriculture and Forestry University, \\ Xianyang 712100, China
}

Received: 2 June 2020

Accepted: 24 August 2020

\begin{abstract}
Wei River, as the largest tributary of the Yellow River, is facing an increasingly serious shortage of water resources. Therefore, it has a great significance to study the correlation between the supplydemand characteristics of water yield service and the spatial matching of supply and demand for the management and efficient allocation of water resources in the region. Based on the land use data, precipitation data, evaporation data, and water consumption data of the Wei River basin in 2000, 2005, 2010, and 2015, we used spatial analysis tools of the InVEST model, ArcGIS and GeoDa to calculate the supply and demand of water yield service in the research area, then analyzed and evaluated the matching status of supply and demand of water yield service in the region. The results showed that: (1) The total water yield of Wei River basin in 2015 increased by 271 million $\mathrm{m}^{3}$ compared with that in 2000, among which the water yield per unit area varies in different categories: unused land $>$ construction land $>$ farm land $>$ grass land $>$ forest $>$ water area; (2) During the study period, water yield service was mostly deficit, and there were differences among different regions. The total supply of water yield service increased year by year, and the total demand decreased firstly and then increased. Spatially water yield service supply is high in the south and low in the north, while demand is relatively stable; (3)The number of low-low spatial matching in Wei River basin was the largest, accounting for $20.43 \%$ of the whole Wei River basin. The high-high spatial matching was mainly concentrated in Guanzhong plain, Xi 'an, Shaanxi province. The high-low spatial dislocation only involved Fengxiang county of Shaanxi province in the south of the study area. The result of this study is helpful for the government to rationally allocate water resources in Wei River basin, and to ensure the high-quality and sustainable development of the ecological environment in Yellow River basin ultimately.
\end{abstract}

Keywords: Wei River basin, water yield service, spatio-temporal research of supply and demand matching, InVEST model

*e-mail: yaoshunbo@163.com 


\section{Introduction}

Ecosystem services are the environmental conditions and utilities formed by the ecosystem to promote human survival and development [1] and are the basis of human survival and development [2]. Among them, water yield service, as an important ecosystem services, has a great significance in maintaining ecosystem stability and human production and life [3,4]. On one hand, water yield service directly affect human wellbeing by offering adequate water for production and domestic use [5]. On the other hand, the tradeoffs and synergies between water yield service and other services indirectly affect the benefits available to humans [6]. However, in recent years, with the rapid development of the economy, the acceleration of urbanization, the continuous increase of the population, and the impact of global climate change, there has been deficit of water yield service in some regions [7]. The imbalance between supply and demand of water will affect regional ecosystems and sustainable socioeconomic development [8]. Therefore, the analysis of the supply characteristics, supply-demand relationships and spatial correlations of regional water yield service will be conducive to the management and effective allocation of water resources in the region.

At present, relevant scholars focused on the following three aspects in their researches on ecosystem water yield service. (1) Research on spatial characteristics of regional water yield service and its future prediction: For example, Wang Baosheng et al. [9] simulated the water conservation situation of the Fujian triangle city cluster in 2015 and 2030 through the InVEST model, and predicted that the overall water conservation quantity in the region of the Fujian triangle city cluster would decline by 2030 . Bastola et al. [10] simulated the total water yield of the Bagmati basin in Nepal by using subbasin scale and studied the water yield capacity of different land use types in the region. Hou Wenjuan et al. [11] selected a typical Karst peak cluster depression basin, and based on the calibrated SWAT hydrological model, simulated flow generation services (including surface and underground surface and total runoff) in the Karst basin. Then she analyzed the spatial variation characteristics of different service variables by combining spatial gradient analysis and local regression model. (2)Research on water yield service or water source conservation function and its driving mechanism . For example, Yang et al. [12] took the typical east Asian monsoon basin in south China as the research object, studied the regional water yield and its influencing factors, and showed that precipitation is the most sensitive factor affecting water yield. Dou Panfeng et al. [8] designed six scenarios to study the effects of climate change and land use/cover change on water yield service of the ecosystem of Ningbo by using the method of scenario analysis. The contribution of climate and land use/cover changes to ecosystem water service was also quantified. Xu Dingxue et al. [13] took Chengde of Zhangjiakou region as the research area and made a simulation calculation of its water yield and soil retention. The changes of land use, water yield and soil conservation service under different elevations and gradients were analyzed. (3)Evaluation of integrated ecosystem service including water yield service. For example, Siniscalchi et al. [14] evaluated ecosystem services based on the mathematical model proposed in the framework of dynamic optimization by comprehensively considering the food supply and water flow of soil and water, so as to solve the management and economic evaluation of ecosystem services in the salt lake basin in the semi-arid area of Argentina. Liu Licheng et al. [15] took Lanzhou city as an example, analyzed and evaluated four services of water and food supply, including carbon fixation and soil conservation, in the research area. Wencui Cong, et al. [16] by using SWAT model and InVEST model to analyse the Nansi lake basin in China with different terrain basin of three Hydrological Ecosystem Services (HES), and compare the results through the space hot-spot analysis on HES. To sum up, in terms of ecosystem water yield service, different scholars have done more research on the comprehensive ecosystem services in a specific period, while the studies on the single ecosystem service function across a large area of time are relatively insufficient. In addition, there is a lack of research on the supply and demand of ecosystem services and the spatial matching of supply-demand from the perspective of quantity matching and spatial matching.

Wei River, the largest tributary of the Yellow River, flows through arid and semi-arid areas mainly. And it is the most important water source for agriculture, industry and other social and economic activities in the Guanzhong Plain. Due to the influence of geological structure, the distribution of water systems in the basin is not symmetrical between north and south. In addition, human beings have cut down large areas of forest, which leading to the highest degree of soil erosion in the loess plateau and with serious water shortage and inefficient utilization of water resources emerged.

The spatial distribution of water resources also varies greatly under the influence of natural conditions such as climate. Therefore, it is significant for regional management of water resources and effective allocation to analyze the relationship between supply and demand of water and spatial matching in Wei River basin. This study started from the supply and demand of water, aiming to solve the following scientific problems: (1) The relationship between supply of water yield service and its land use type in Wei River basin. (2) Spatial and temporal distribution characteristics of water supply and demand in Wei River basin; (3) Spatial matching of supply and demand of water yield service in Wei River basin. To some extent, this study can enrich the research on ecosystem services. It has great practical significance to improve the efficient utilization of water resources in Wei River basin, to accelerate the economic and social development of Wei River basin 
and its related areas and to optimize the supply and demand pattern of regional water yield service and rationally allocate water resources. Finally, it aims to provide scientific reference for ecological protection and high-quality development of the Yellow River basin.

\section{Material and Methods}

\section{Area of the Study}

Wei River basin, located at $34^{\circ} \sim 38^{\circ} \mathrm{N}$ and $104^{\circ} \sim 110^{\circ} \mathrm{E}$, is the largest tributary of the Yellow River in China with an area of about $132,600 \mathrm{~km}^{2}$. The valley is high in the west and low in the east, with ravines and crisscross. And the total length is $211 \mathrm{~km}$ (Fig. 1). The surface of the main soil is thick loess and it has a single management mode. Due to the influence of geographical location and topography, the runoff in the basin and the annual variation are small. The tributaries are small and long and the water energy resources are scarce. The main tributaries include Jing River, Beiluo River and so on. Most of the Wei River basin has a warm temperate semi-arid and semi-humid climate with typical continental monsoon characteristics. The average annual precipitation is about $600 \mathrm{~mm}$, which is more in the south and less in the north, and more in the west and less in the east. The annual precipitation varies greatly, mainly concentrates from May to October during the flood season. The average annual evaporation was $700 \sim 1200 \mathrm{~mm}$, and the distribution pattern was opposite to the precipitation. The evaporation in June and July was the largest, accounting for about $45 \% \sim 60 \%$ of the annual evaporation. Hot and rainy in summer, cold and dry in winter. The average temperature is $8 \sim 14^{\circ} \mathrm{C}$, which declines with the two sides of Wei River. Wei River basin is located in the deciduous and broadleaved forest belt in the warm temperate zone. However, due to the man-made destruction, the phenomenon of deforestation and the vegetation destruction are serious. At present, the second-growth forest and grass land are in the majority. In 1999, the Wei River basin took the lead in returning farmland to forests. After 20 years, the ecological environment has been greatly improved and soil erosion has been effectively controlled.

\section{Data Sources and Processing}

In terms of attributes, the data of this study mainly covers natural background data and socio-economic data. The utility mainly includes two parts: water yield service supply mapping and water yield service demand mapping.

(1) Water yield service supply simulation data. The input parameters of the water yield module of InVEST model include land use data (first-level ground type), meteorological element data, soil basic data and biophysical parameters, etc. The spatial resolution of all data was resampled to $90 \mathrm{~m} \times 90 \mathrm{~m}$, and uniformly converted to WGS_1984_UTM_Zone_49N projection

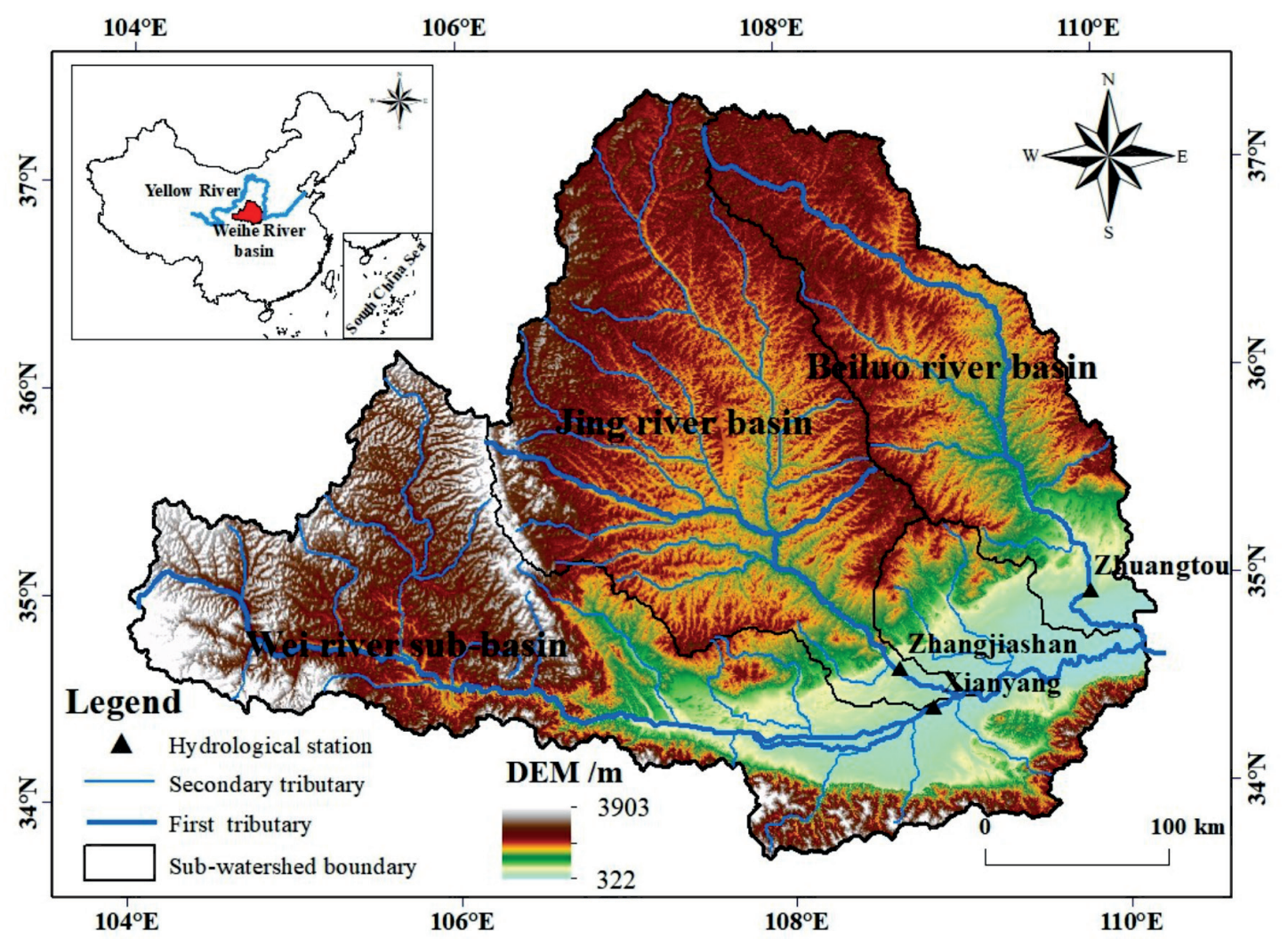

Fig. 1. Location of the Wei River Basin. 


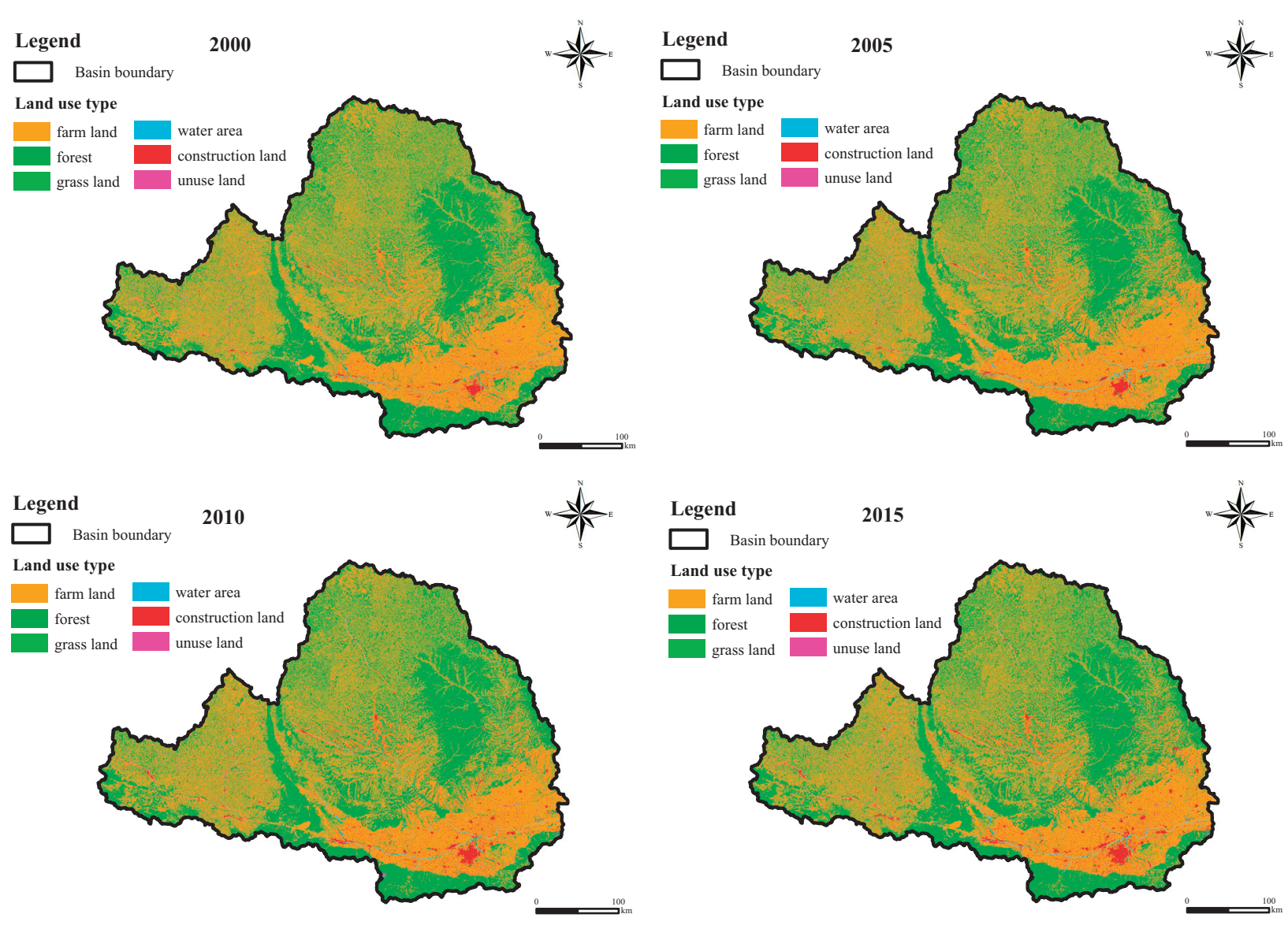

Fig. 2. Land use types of Wei River Basin from 2000 to 2015.
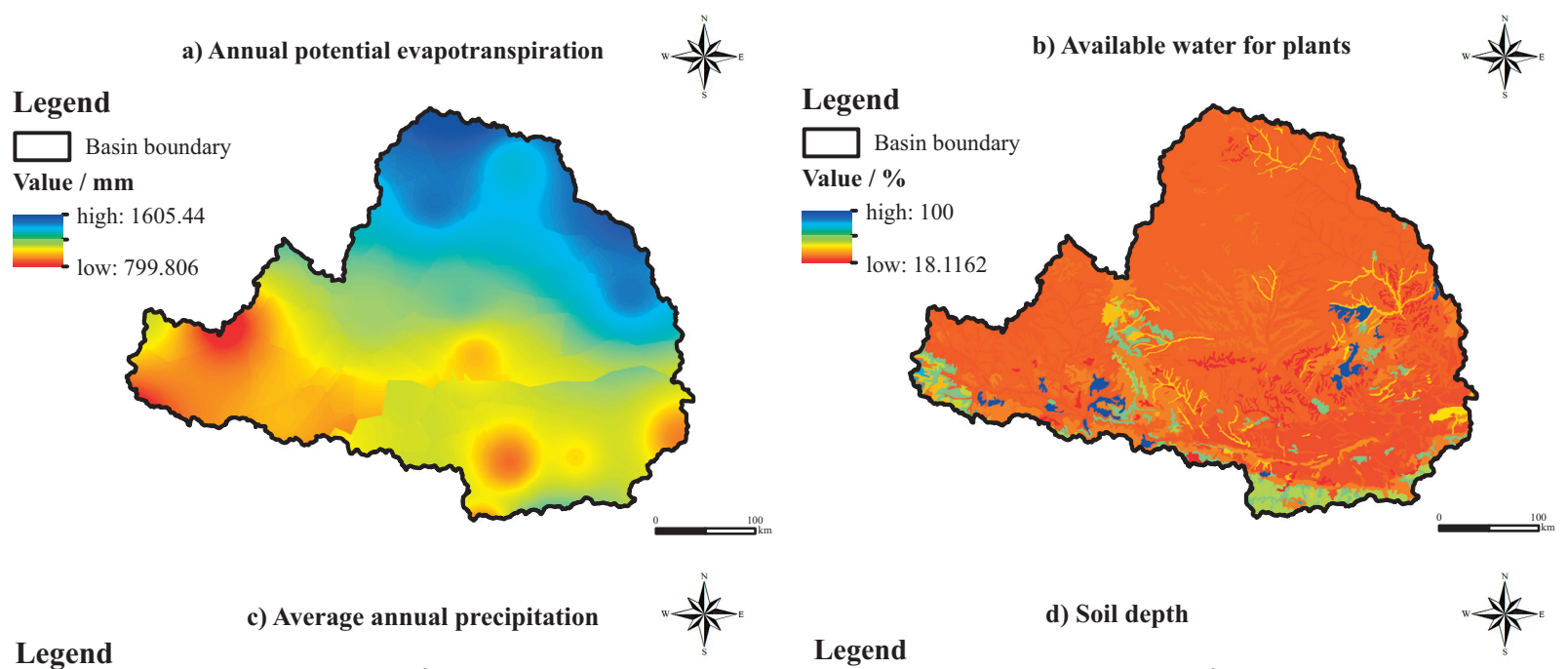

\section{Legend}

c) Average annual precipitation
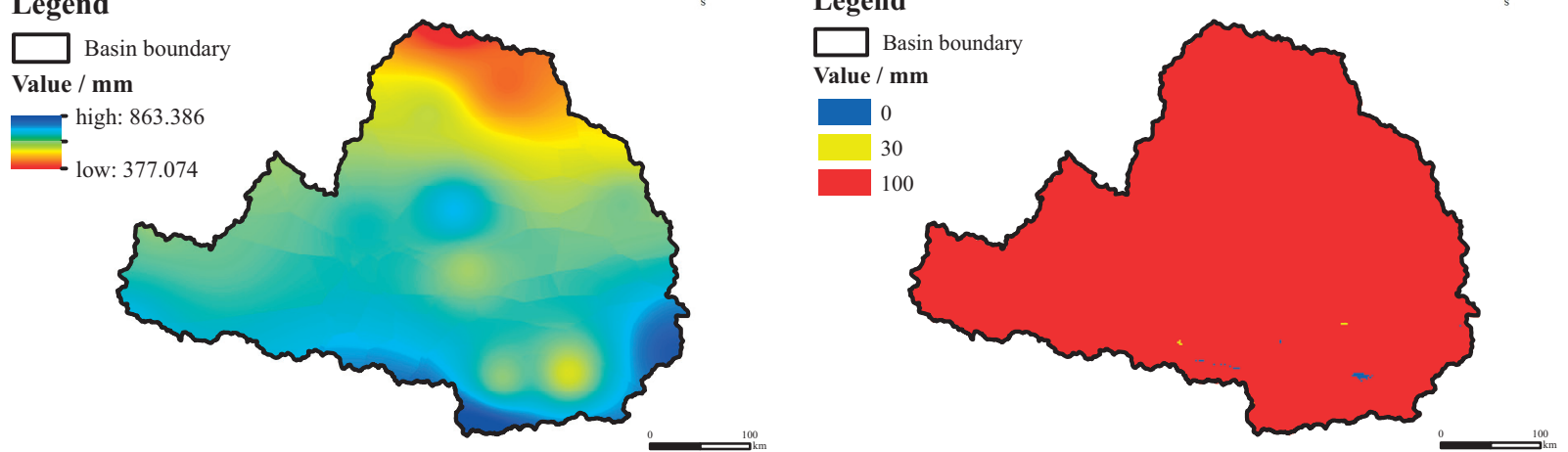

Fig. 3. InVEST Model space layer data. 
to ensure the consistency of all data in space. Land use data (Fig. 2) is provided by Data Center for Resources and Environmental Sciences, Chinese Academy of Science(RESDS)(http://www.resdc.cn), including the data of the 4 phases of 2000, 2005, 2010 and 2015. The production of this data set takes LandsatTM, ETM+ and OLS remote sensing images of each period as the data source and is generated by manual visual interpretation. After field verification, the accuracy of land use and type comprehensive evaluation after error correction is more than 93\% [17-19]. According to the Chinese land resource classification system established by the "national remote sensing survey and dynamic research on resources and environment" project [20], the land use types in Wei River basin are reclassified into 6 first-level land types: farm land, forest, grass land, water area, construction land and unused land. The evaporation data (Fig. 3a) were calculated by Hamon formula [21] and then the inverse distance interpolation was carried out. PAWC (Fig. 3b) can be calculated according to the soil texture data and the empirical formula [22]. Precipitation data (Fig. 3c) are from the Chinese meteorological administration (http://data.cma. $\mathrm{cn} /$ ). In order to avoid the low representativeness of data in a single year, the multi-year mean of meteorological data during a period of time (1998-2002, 2003-2007, 2008-2012, 2013-2017) was selected, and then the mean value was taken (based on a small difference in data) for inverse distance interpolation. Soil depth (Fig. 3d) was derived from the Chinese soil data set $(1: 1,000,000)$ in the world soil database (HWSD) constructed by FAO and IIASA. Biophysical parameters were obtained by referring to the research results of others [23-25].

(2) Water resource demand accounting data. The total demand for water resources consists of agricultural water, industrial water, domestic water and ecological water. Population data of Wei River basin in 2000, 2005, 2010 and 2015 were from Chinese county Statistical Yearbook, and water resource demand data for different uses were from Water Resources Bulletin of Shaanxi, Gansu province and Ningxia Hui Autonomous Region.

\section{Research Methods}

\section{Research Framework}

Based on the supply and demand of water in Wei River basin, we constructs the research framework to explore the supply-demand relationship and spatial distribution characteristics of water yield service in Wei River basin (Fig. 4). (1) Combined with the basic spatial data and the water yield module of the InVEST model, the water yield service of Wei River basin was simulated and quantitatively evaluated (that is, the amount of supply). And the results were verified. (2) The water consumption (that is, the amount of demand) of the study area was obtained by collecting data from Chinese County Statistical Yearbook and Water Resources Bulletin of Shaanxi province, Gansu
Province and Ningxia Hui Autonomous Region.(3) Based on the supply and demand of water yield service, the relationship between supply and demand of water yield service in the region and its spatial distribution characteristics are obtained respectively through the calculation of supply-demand ratio and the local Moran's I.

\section{Supply and Demand Assessment of Water Yield Service}

(1) InVEST model for water yield service

InVEST (Integrated Valuation of Ecosystem Services and trade-offs) tool [26-28] is an open source valuation software jointly developed by Stanford University, University of Minnesota, the Nature Conservancy and WWF, with strong spatial analysis ability and evaluation accuracy [29]. The Water Yield sub-module in the model is used widely for the water yield service quantity. "Water Yield" includes soil water content of surface runoff, litter water holding capacity and canopy interception, etc. The interaction between surface water and groundwater is not considered. Based on the balance principle of Budyko curve [30] and average annual precipitation, the water yield was calculated by such parameters as surface evaporation depth and soil depth of dewatering plants, that is, the rainfall of a certain grid unit minus the actual evaporation was the water yield. The main algorithm formula of the model is as follows:

$$
Y(\mathrm{x})=\left(1-\frac{A E T(x)}{P(x)}\right) \cdot P(x)
$$

In formula (1), $A E T(x)$ represents the actual annual evaporation of grid cells, and $P(x)$ represents the annual precipitation of grid cells.

In the equation of water balance, vegetation evaporation of land use type is calculated using the equation of Budyko hydrothermal coupling equilibrium hypothesis proposed by FU [31] and Zhang et al. [32]:

$$
\frac{A E T(x)}{P(x)}=1+\frac{P E T(x)}{P(x)}-\left[1+\left(\frac{P E T(x)}{P(x)}\right)^{w}\right]^{1 / w}
$$

In formula (2), PET(x) represents the potential evaporation, which is calculated by Hamon formula [21]:

$$
\begin{gathered}
P E T_{\text {Hamon }}=13.97 d D^{2} W_{t} \\
W_{t}=4.95 e^{0.062 T / 100} \\
T=T_{\text {max }}+T_{\text {min }} / 2
\end{gathered}
$$

In formula (3)-(5), $d$ represents the days of each month, $D$ represents the average monthly sunshine hours 


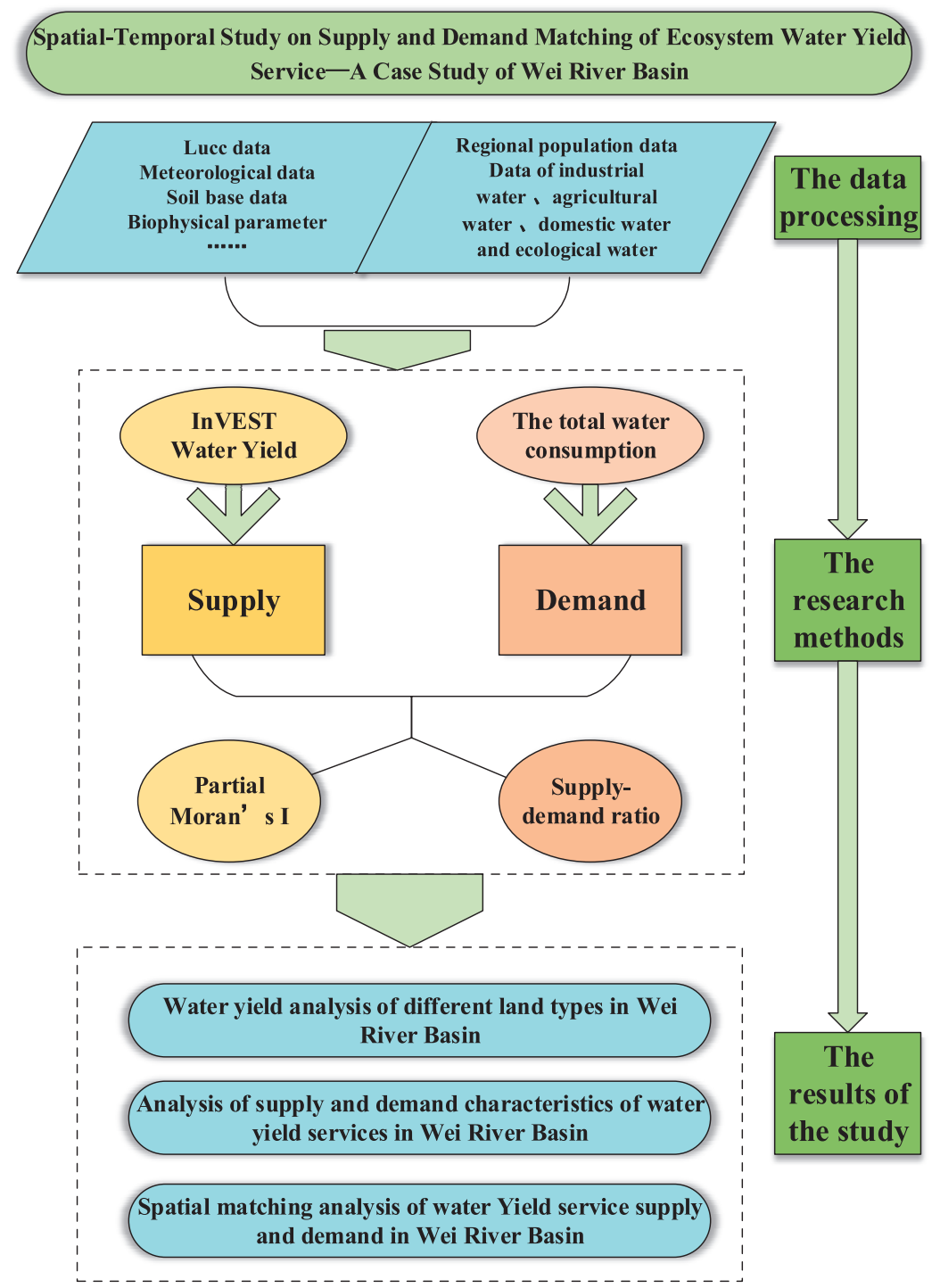

Fig. 4. Research framework of ecosystem water yield service in Wei River Basin.

calculated by year (in units of 12 hours), $W_{t}$ represents the saturated water vapor density, $T$ represents the monthly average temperature and the unit is ${ }^{\circ} \mathrm{C}, T_{\max }$ represents the monthly average maximum temperature, and $T_{\min }$ represents the monthly average minimum temperature. When the monthly mean temperature is less than 0 degrees, the potential evaporation is 0 . The sum of the monthly potential evaporation of PET from each grid cell was converted into the annual potential evaporation during the study period.

$w(x)$ is an empirical parameter, expressed by the formula proposed by Donohue et al.[33], which is defined as:

$$
w(x)=Z \frac{A W C(x)}{P(x)}+1.25
$$

In formula (6), $Z$ is the empirical constant, also known as "the seasonal constant", which can represent the regional precipitation distribution and other hydrogeological characteristics. After continuous debugging, $Z$ is 8 , which is the closest to the measured results. $A W C(x)$ was determined by the soil texture and the soil effective depth, which represents the soil effective water content ( $\mathrm{mm})$. It is used to determine the total amount of water for the storage and growth of plants provided by the soil.

$A W C(x)=\operatorname{Min}($ Rest.layer.depth, root.depth $) \cdot P A W C$

In formula (7), Rest.layer.depth is the maximum root burial depth of soil, and root.depth is the root depth of plants, $P A W$ indicates the water for plants used effectively, which is calculated by the empirical formula [22]:

$$
\begin{gathered}
P A W C=54.509-0.132 \text { sand }-0.003(\text { sand }) \\
-0.055 \text { silt }-0.006(\text { silt })^{2}-0.738 \text { clay }+0.007(\text { clay })^{2} \\
-2.688 O M)^{2}+0.501(O M)^{2}
\end{gathered}
$$


In formula (8), sand is the soil sand content (\%); silit is soil powder content (\%): clay is soil clay content $(\%)$; $O M$ is the content of soil organic matter (\%).

The depth plant evaporation coefficient $(\mathrm{Kc})$ and Velocity coefficient (Velocity) of plant roots were obtained from relevant literature [28-30], and the biophysical parameter was listed after sorting (Table 1).

(2) Water yield service demand

In this study, the water yield service demand mainly includes the consumption of agricultural water, industrial water, domestic water and ecological water. Industrial water refers to the direct or indirect water consumption in industrial production, mostly including the water for raw material, product treatment and cooling. Agricultural water is used for farm irrigation and rural livestock. Domestic water includes water for daily life and water for public services (i.e., water for urban social public life services) [34]. Ecological water refers to surface water, groundwater and soil water, which is necessary to maintain relative stability of ecosystems. The specific calculation formula is as follows:

$$
D_{i}=D_{\text {indus }}+D_{\text {agric }}+D_{\text {life }}+D_{\text {eco }}
$$

In formula (9): $D_{i}$ represents the total water consumption of the area $i$ (i.e. the demand for water yield service), $D_{\text {indus }}$ represents the industrial water consumption of the area $i, D_{\text {agric }}$ represents the agricultural water consumption of the area $i, D_{\text {life }}$ represents the domestic water consumption of the area $i, D_{\text {eco }}$ represents the ecological water consumption of the area $i$.

(3) Water yield service supply and demand ratio

Here, the ratio of water yield service supply quantity to water demand is used to reveal the nature of surplus or shortage of regional water service. The calculation formula is as follows:

$$
S D R=S / D
$$

In formula (10): $S D R$ represents the supply-demand ratio of water yield service, $S$ and $D$ represent the actual supply and demand of water respectively.

Table 1. Biophysical parameters of the Wei River Basin.

\begin{tabular}{|c|c|c|c|c|}
\hline Land use type & Lucode & $\mathrm{kc}$ & root_depth & LULC_Veg \\
\hline Farm land & 1 & 0.65 & 350 & 1 \\
\hline Forest & 2 & 1 & 3000 & 1 \\
\hline Grass land & 3 & 0.65 & 500 & 1 \\
\hline Water area & 4 & 1 & 1 & 0 \\
\hline Construction land & 5 & 0.3 & 1 & 0 \\
\hline Unused land & 6 & 0.3 & 10 & 0 \\
\hline
\end{tabular}

$S D R>1$ represents the oversupply of water yield service, $S D R=1$ represents the balance between water supply and demand; $S D R<1$ means demand exceeds supply of water.

(4) Spatial matching of supply and demand of water yield service

Spatial exploratory analysis method (ESDA) is applied to explore the spatial distribution and spatial association pattern of the research object. Generally, ESDA has global and local indexes, and most of them use Moran index to test and measure [35]. To achieve spatial correlation analysis of multivariate variables, Wartenberg improved and proposed Multivariate Moran's I [36]. In this study, Multivariate Moran's I was applied to conduct the analysis of spatial matching between supply and demand of water in Wei River basin, and the spatial matching pattern of supply and demand of water was revealed through a visual LISA diagram. The variables here are the supply and demand of regional water, and the specific calculation formula is as follows:

$I_{y}=\frac{n}{\sum_{i} \sum_{j} w_{j}} \times \frac{\sum_{i} \sum_{j} w_{j}\left(\text { water }_{D}-\overline{\text { water }_{D}}\left(\text { water }_{S}-\overline{\text { water }_{S}}\right)\right.}{\sqrt{\sum_{i}\left(\text { water }_{D}-\overline{\text { water }_{D}}\right)^{2}} \sqrt{\sum_{j}\left(\text { water }_{S}-\overline{\text { water }_{S}}\right)^{2}}}$

In formula (11): $w_{i j}$ is the spatial weight matrix between regions $i$ and $j$; water $_{D j}$ is the water demand for region $i$, water ${ }_{S j}$ is the water supply for region $j$, $\overline{\text { water }}_{D}$ and $\overline{\text { water }}_{S}$ are the average values of all water supply and demand in the sample; $n$ is the total number of regional areas. $I_{x y}$ is Moran \& apos's I, and its value is between -1 and $1, I_{x y}>0$ indicating that there is a positive spatial correlation between the two variables. The greater the value, the more obvious the positive spatial correlation. $I_{x y}<0$ represents the negative spatial correlation. The smaller the value, the more obvious the negative spatial correlation, and $I_{x y}=0$ represents the spatial random distribution.

\section{Results}

\section{Model Result Verification}

Model verification refers to the comparison of model operation results with measured data. In this paper, by referring to the previous model calibration method [8, 37-38], we simulated and calculated the water yield of Wei River basin repeatedly. Here we took an average of our results from 2000 to 2015 and compared with runoff of Wei River basin of "Yellow River silt measured data in the communique" (Table 2). And then we validated the result of the corresponding hydrological site 3 of Wei River basin according to the years of average runoff ( \pm standard deviation). Results shown that the simulation values of Jing River, Wei River (tributaries) and Beiluo 
Table 2. Water yield in Wei River Basin.

\begin{tabular}{|c|c|c|c|c|c|}
\hline Basin & Export station & Area $\left(\mathrm{km}^{2}\right)$ & $\begin{array}{c}\text { Annual yield }\left(10^{8} \mathrm{~m}^{3}\right) \\
2000-2015\end{array}$ & Ratio (\%) & $\begin{array}{c}2009 \text { (annual average) } \\
\text { Measured value }\left(10^{8} \mathrm{~m}^{3}\right)\end{array}$ \\
\hline Beiluo River & Zhuangtou & 27794.80 & 9.13 & 11.55 & 8.48 \\
\hline Jing River & Zhangjiashan & 45431.14 & 23.51 & 29.73 & 16.73 \\
\hline Wei (tributary) & Xianyang & 59149.77 & 46.44 & 58.72 & 42.42 \\
\hline
\end{tabular}

River are more than the measured values of hydrology station (Fig. 5). The determination coefficient $\mathrm{R}^{2}$ between them is 0.9756 , which indicating that the simulated results of the model are reliable. This provided a strong guarantee to the subsequent analysis of the paper.

\section{Analysis of the Water Yield of Wei River Basin}

\section{Comparison and Analysis of Water Yield of Different Land Use Types}

The total water output of Wei River basin in 2015 increased by 271 million $\mathrm{m}^{3}$ compared with that in 2000 (Table 3). The main land use types of Wei River basin are farm land, forest and grass land, accounting for more than $95 \%$ of the total area of the basin. In addition, the water yield of farm land, forest and grass land is different. The farm land produced water of 3.64 billion $\mathrm{m}^{3}$ in 2000 and 3.43 billion $\mathrm{m}^{3}$ in 2015 , respectively. And forest produced water of 413 million $\mathrm{m}^{3}$ in 2000 and 448 million $\mathrm{m}^{3}$ in 2015. The grass land produced water of 1.85 billion $\mathrm{m}^{3}$ in 2000 and 1.78 billion $\mathrm{m}^{3}$ in 2015 . And it showed the water yield of farm land $>$ grass land $>$ forest. From the perspective of water yield per unit area, we found that the unused land is $351,000 \mathrm{~m}^{3}$ in 2000 and $319,000 \mathrm{~m}^{3}$ in 2015 , followed by construction land with water yield per unit area of more than $300,000 \mathrm{~m}^{3}$, less farm land and grass land, and forest land with water yield of only $14,500 \mathrm{~m}^{3}$, that
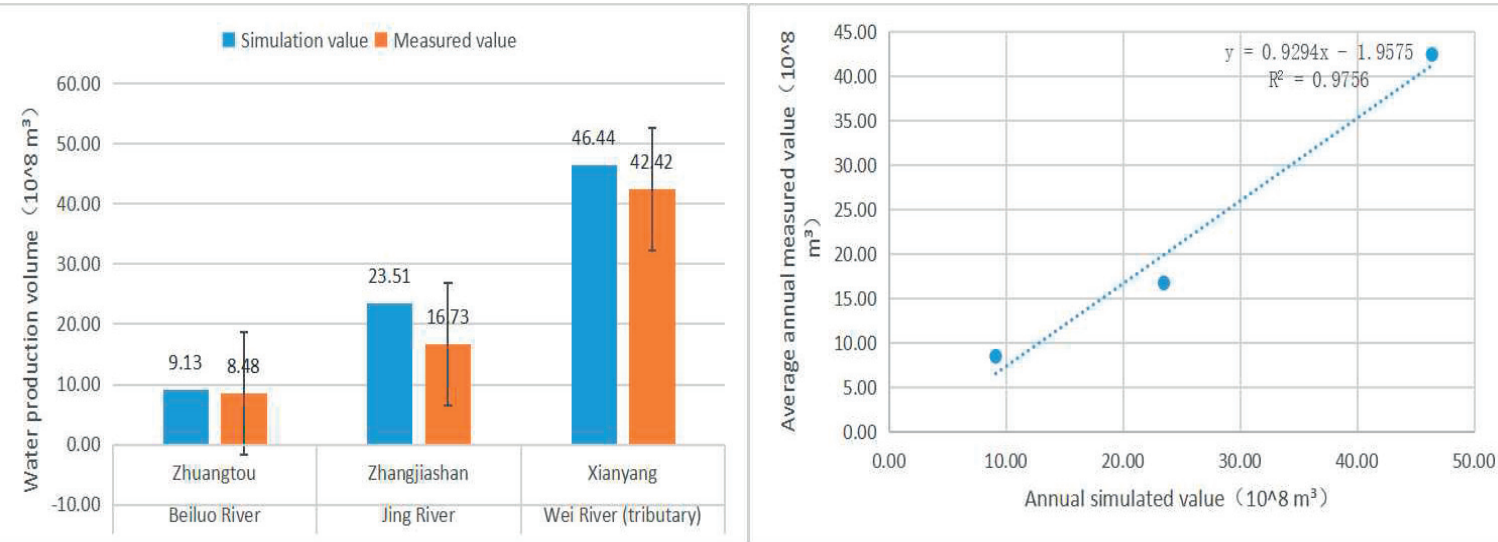

Fig. 5. Model verification results.

Table 3. Comparison and analysis of water yield of different land use types in the Wei River Basin.

\begin{tabular}{|c|c|c|c|c|c|c|}
\hline & \multicolumn{3}{|c|}{2000} & \multicolumn{3}{c|}{2015} \\
\hline Land use type & $\begin{array}{c}\text { Area } \\
\left(\mathrm{km}^{2}\right)\end{array}$ & $\begin{array}{c}\text { Total water yield } \\
\left(10^{8} \mathrm{~m}^{3}\right)\end{array}$ & $\begin{array}{c}\text { Water yield per unit area } \\
\left(10^{8} \mathrm{~m}^{3}\right)\end{array}$ & $\begin{array}{c}\text { Area } \\
\left(\mathrm{km}^{2}\right)\end{array}$ & $\begin{array}{c}\text { Total water yield } \\
\left(10^{8} \mathrm{~m}^{3}\right)\end{array}$ & $\begin{array}{c}\text { Water yield per unit } \\
\text { area }\left(10^{8} \mathrm{~m}^{3}\right)\end{array}$ \\
\hline Farm land & 59800 & 36.4 & 6.08 & 56200 & 34.3 & 6.10 \\
\hline Forest & 28400 & 4.13 & 1.45 & 30800 & 4.48 & 1.45 \\
\hline Grass land & 39900 & 18.5 & 4.64 & 39200 & 17.8 & 4.54 \\
\hline Water area & 804 & 0 & 0.00 & 873 & 0 & 0 \\
\hline Construction land & 3600 & 10.9 & 30.4 & 5260 & 15.9 & 30.3 \\
\hline Unused land & 136 & 0.48 & 35.1 & 202 & 0.64 & 31.9 \\
\hline Total & 132640 & 70.41 & 77.67 & 132535 & 73.12 & 74.29 \\
\hline
\end{tabular}


is, unused land $>$ construction land $>$ farm land $>$ grass land $>$ forest $>$ water area.

\section{Analysis of Water Yield Change of Land Use Types}

To further analyze the relationship between land use types and water yield, the regional analysis of spatial analysis in ArcGIS was used to obtain the water yield under the land use of 2000, 2005, 2010 and 2015 as shown in Table 4. The annual water output of different land use in the Wei River basin has changed significantly. During the study period, the water yield of farm land showed a downward trend, from 3.64 billion $\mathrm{m}^{3}$ in 2000 to 3.43 billion $\mathrm{m}^{3}$ in 2015 , with a decrease of 210 million $\mathrm{m}^{3}$, but its proportion was still the largest, more than $45 \%$. The water yield of forest showed a small increasing trend, with an increase of only 0.4 billion $\mathrm{m}^{3}$ from 2000 to 2015 , only about $6 \%$ among the three land use types. The water yield of grass land fluctuates, with an decrease of about 0.7 billion $\mathrm{m}^{3}$. In addition, the water yield of construction land has an growth of $2.49 \%$, with an increase of 490 million $\mathrm{m}^{3}$. The comparison of land use types in the study period, the farm land area continued to decrease, from $59800 \mathrm{~km}^{2}$ in 2000 to $56200 \mathrm{~km}^{2}$ in 2015 , with a total decreasing area of $3600 \mathrm{~km}^{2}$. From 2005 to 2010, the farm land area decreased mostly, with a decrease of $1.58 \%$, about $2100 \mathrm{~km}^{2}$. The forest area continuously increased from 2000 to 2015, with an average annual increasing rate of $0.542 \%$. The grass land area decreased first and then increased. The construction land continued to increase during the study period, from $3600 \mathrm{~km}^{2}$ in 2000 to $5260 \mathrm{~km}^{2}$ in 2015 .
Analysis of Supply and Demand Characteristics of Water Yield service in Wei River Basin

\section{Spatial and Temporal Changes of Supply and Demand of Water Yield Service}

From the perspective of supply and demand (Table 5), the total supply of water in Wei River basin showed an increasing trend year by year, rising from 7.0401 billion $\mathrm{m}^{3}$ in 2000 to 7.3126 billion $\mathrm{m}^{3}$ in 2015, with an increase of 272.5 million $\mathrm{m}^{3}$. Total demand of water showed a "V-shaped" trend of decrease and then increase. It can be seen that the total supply of water in Wei River basin is less than the total demand. There are still differences among regions. The Wei River basin covers 59 counties in Shaanxi, 28 counties in Gansu and 6 counties in Ningxia. As it can be seen from Table 3, during the study period, the supply and demand of water in Shaanxi province presented an upward trend, increasing from 3.241 billion $\mathrm{m}^{3}$ (supply) and 4.8232 billion $\mathrm{m}^{3}$ (demand) in 2000 to 3.4762 billion $\mathrm{m}^{3}$ (supply) and 5.9639 billion $\mathrm{m}^{3}$ (demand) in 2015 respectively. During the study period, the supply quantity in Gansu province presented a fluctuation trend of "increasing - decreasing increasing", while the demand showed an inverted "U-shaped" trend of increasing first and then decreasing. During the study period, the supply quantity of Ningxia remained basically unchanged, all of which were about 330 million $\mathrm{m}^{3}$. On the other hand, the demand showed a significant downward trend, which decreased from 2.4794 billion $\mathrm{m}^{3}$ in 2000 to 1.4394 billion $\mathrm{m}^{3}$ in 2015 , with a decrease of 1.04 billion $\mathrm{m}^{3}$.

Table 4. Land use change and water yield change.

\begin{tabular}{|c|c|c|c|c|c|c|c|}
\hline Year & Land use type & Farm land & Forest & Grass land & Water area & Construction land & Unused land \\
\hline \multirow{4}{*}{2000} & Area $\left(\mathrm{km}^{2}\right)$ & 59800 & 28400 & 39900 & 804 & 3600 & 136 \\
\hline & Ratio(\%) & 45.1 & 21.4 & 30.1 & 0.6 & 2.7 & 0.1 \\
\hline & Water yield $\left(10^{8} \mathrm{~m}^{3}\right)$ & 36.4 & 4.1 & 18.5 & 0 & 11 & 0.5 \\
\hline & Ratio (\%) & 51.6 & 5.9 & 26.2 & 0 & 15.6 & 0.7 \\
\hline \multirow{4}{*}{2005} & Area $\left(\mathrm{km}^{2}\right)$ & 58900 & 30200 & 38600 & 886 & 3940 & 117 \\
\hline & Ratio(\%) & 44.4 & 22.8 & 29.1 & 0.7 & 3 & 0.1 \\
\hline & Water yield $\left(10^{8} \mathrm{~m}^{3}\right)$ & 35.9 & 4.3 & 17.8 & 0 & 12 & 0.4 \\
\hline & Ratio (\%) & 51 & 6.1 & 25.3 & 0 & 17 & 0.6 \\
\hline \multirow{4}{*}{2010} & Area $\left(\mathrm{km}^{2}\right)$ & 56800 & 30300 & 39900 & 842 & 4600 & 145 \\
\hline & Ratio(\%) & 42.8 & 22.9 & 30.1 & 0.6 & 3.5 & 0.1 \\
\hline & Water yield $\left(10^{8} \mathrm{~m}^{3}\right)$ & 34.7 & 4.4 & 18.3 & 0 & 13.9 & 0.5 \\
\hline & Ratio (\%) & 48.3 & 6.1 & 25.5 & 0 & 19.4 & 0.7 \\
\hline \multirow{4}{*}{2015} & Area $\left(\mathrm{km}^{2}\right)$ & 56200 & 30800 & 39200 & 873 & 5260 & 202 \\
\hline & Ratio(\%) & 42.4 & 23.2 & 29.6 & 0.7 & 4 & 0.2 \\
\hline & Water yield $\left(10^{8} \mathrm{~m}^{3}\right)$ & 34.3 & 4.5 & 17.8 & 0 & 15.9 & 0.6 \\
\hline & Ratio (\%) & 46.9 & 6.1 & 24.3 & 0 & 21.7 & 0.9 \\
\hline
\end{tabular}


Table 5. Changes in supply and demand of water yield service in Wei River Basin Unit: $10^{8} \mathrm{~m}^{3}$

\begin{tabular}{|c|c|c|c|c|c|c|c|c|c|}
\hline \multicolumn{2}{|c|}{} & \multicolumn{2}{|c|}{2000} & \multicolumn{2}{c|}{2005} & \multicolumn{2}{c|}{2010} & \multicolumn{2}{c|}{2015} \\
\cline { 3 - 11 } \multicolumn{2}{|c|}{} & $\begin{array}{c}\text { Supply } \\
\text { quantity }\end{array}$ & $\begin{array}{c}\text { Demand } \\
\text { quantity }\end{array}$ & $\begin{array}{c}\text { Supply } \\
\text { quantity }\end{array}$ & $\begin{array}{c}\text { Demand } \\
\text { quantity }\end{array}$ & $\begin{array}{c}\text { Supply } \\
\text { quantity }\end{array}$ & $\begin{array}{c}\text { Demand } \\
\text { quantity }\end{array}$ & $\begin{array}{c}\text { Supply } \\
\text { quantity }\end{array}$ & $\begin{array}{c}\text { Demand } \\
\text { quantity }\end{array}$ \\
\hline \multirow{3}{*}{$\begin{array}{c}\text { Wei } \\
\text { River } \\
\text { Basin }\end{array}$} & Shaanxi & 32.410 & 48.232 & 32.310 & 49.472 & 33.865 & 54.368 & 34.762 & 59.639 \\
\cline { 2 - 11 } & Gansu & 34.641 & 52.459 & 34.730 & 52.603 & 34.545 & 53.813 & 34.954 & 51.858 \\
\cline { 2 - 11 } & Ningxia & 3.351 & 24.794 & 3.366 & 21.894 & 3.377 & 15.784 & 3.410 & 14.394 \\
\hline
\end{tabular}

From the perspective of spatial distribution, the supply of water in Wei River basin presents a high distribution pattern in the south and a low distribution pattern in the north (Fig. 6), while the demand of water presents a large area of stable state (Fig. 7). Specifically, the supply of water in Wei River basin increased gradually from north to south, and the areas with high supply of water are mainly concentrated in Guanzhong area of Shaanxi in the southeast of the basin, followed by Longxi and Tongwei counties (districts) in southwest of China. At the same time, the annual output of water supply in 2015 in the southwest of Wei River basin reduced compared with that in 2000, while the annual output of water service supply in Guanzhong region increased slightly compared with that in 2000. The demand of water in Wei River basin did not change significantly in most areas during the study period. However, Xiji county, Longde County and Yuanzhou district of Ningxia had a dramatic change. And among them, Yuanzhou district had the greatest variation, followed by Xiji County. High demand areas of water are mainly distributed in Yanta District, Heyang County, Jingbian of Shaanxi Province, Lintao County, Huining County of Gansu Province, and Yuanzhou District, Ningxia. The greatest demand was found in Lintao County, Gansu and Yanta District, Shaanxi. This is mainly closely related to regional geographical location and its economic development.
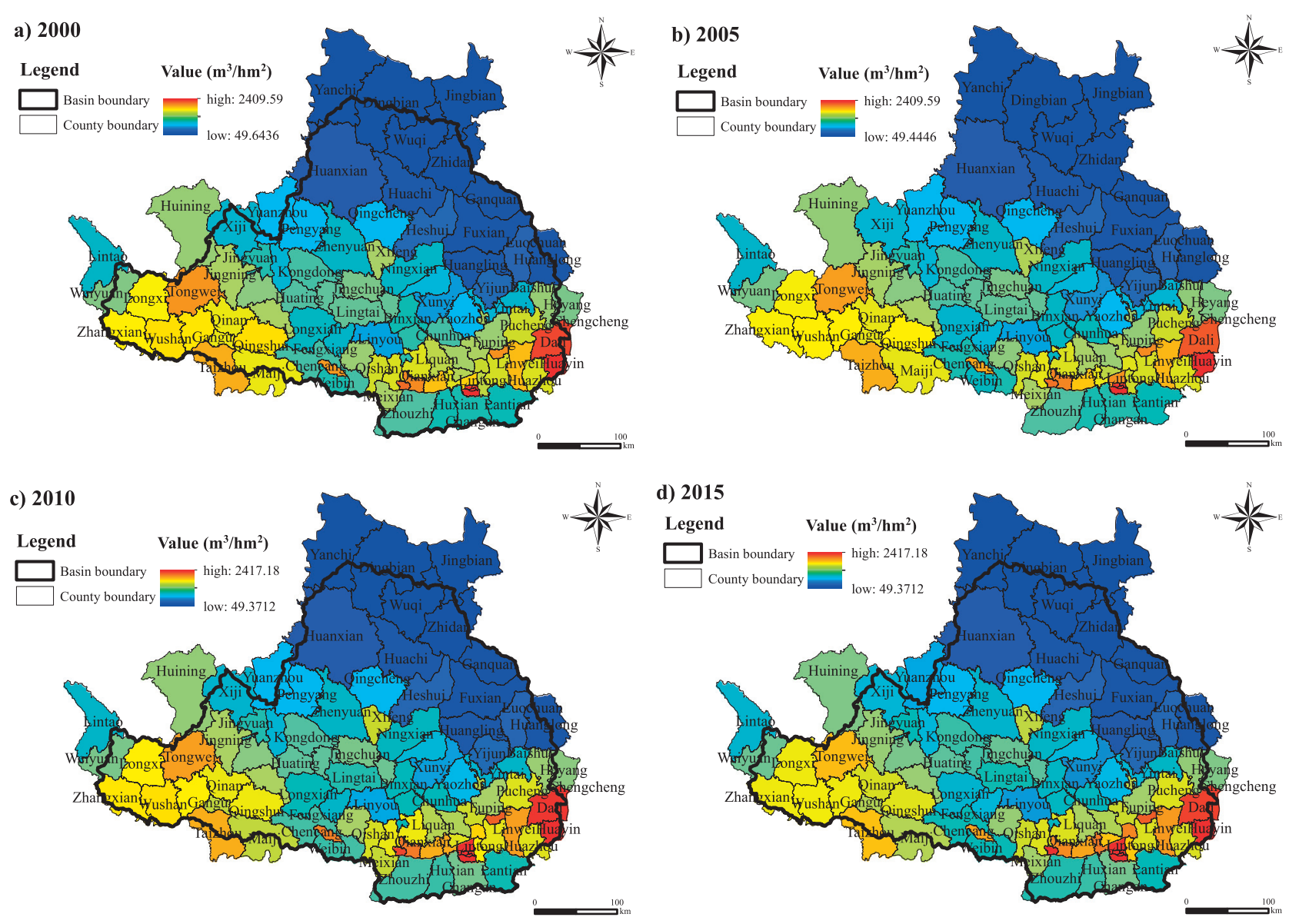

Fig. 6. Spatial changes in supply of water yield service in Wei River Basin. 

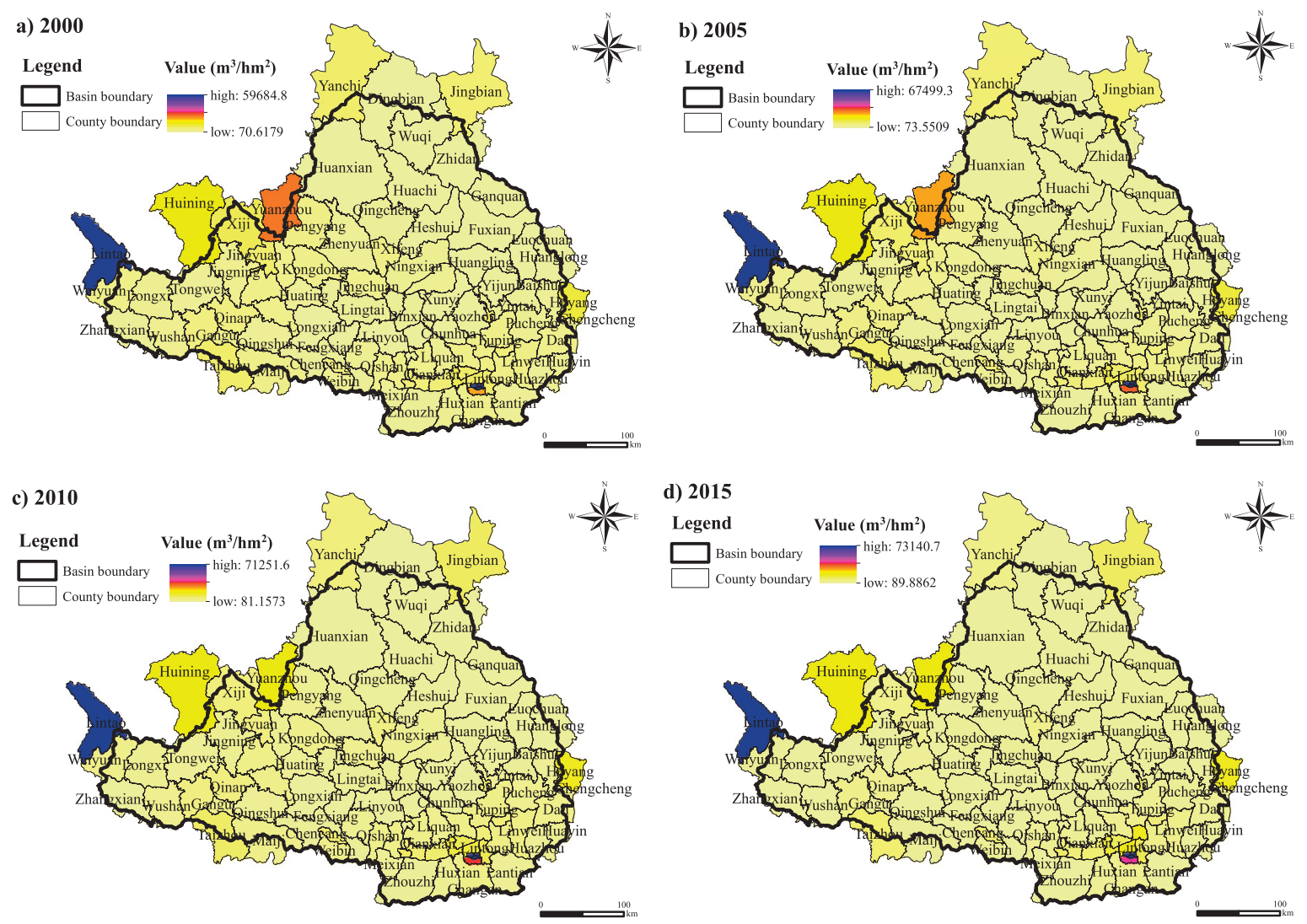

Fig. 7. Spatial changes in demand of water yield service in Wei River Basin.

\section{Temporal and Spatial Variation of Surplus (Deficit) of Water Yield Service}

After simulating and calculating the supply and demand of water in each county (district) of Wei River basin, the ratio is calculated according to formula (10). The balance of supply and demand of water (supply = demand) was considered as the dividing standard of surplus (supply exceeds demand) and deficit (demand exceeds supply). Median clustering method was used to classify surplus and deficit areas of water yield service respectively. Finally, spatial classification was performed by ArcGIS visualization function, and the result was shown in Fig. 8.

From the perspective of time (Fig. 8), the regional distribution of water supply-demand ratio in Wei River basin has not changed significantly. However, with the advance of time and the development of social economy, the supply-demand ratio of water in all regions has been improved to a small extent. This indicates that the demand of water improved gradually. Among them, the water yield service of Lantian County in Shaanxi province had changed from a deficit in 2000 to a surplus in 2015, indicating that the water resources in this region have been rationally and effectively utilized.

From the perspective of spatial distribution (Fig. 8), the water yield service of Wei River basin in 2000, 2005, 2010 and 2015 were basically in the state of deficit in the northwest and southeast, and the state of surplus mainly in the east and near the main road of sub-basins. The number of deficit counties (districts) was larger than that of surplus counties (districts), the former was about 3 times as large as the latter. Specifically, the high-deficit counties (districts) included Yanchi County in Ningxia, Huining County in Gansu and the vicinity of the main urban area of $\mathrm{Xi}$ 'an. Lowdeficit counties (districts) mainly concentrated in the northwest and south parts of the Wei River Basin. The low-deficit counties (districts) were located in the north of the basin near Huashi county and near the main road of Wei River sub-basin. Surplus counties (districts) were mostly clustered near the Wei River and Beiluo River. These were mainly affected by the regional water resources endowment and economic development.

\section{Spatial Matching Analysis of Supply and Demand of Water Yield Service in Wei River Basin}

The spatial matching relationship between supply and demand of water yield service in Wei River basin was analyzed by Moran Index. Based on GeoDa software, the local Moran's I of Wei River basin from 2000 to 2015 (Table 6 and Fig. 9) was 0.427, 0.444, 0.459 and 0.466 , respectively. The $Z$ value was 8.182 , $8.482,8.680$ and 8.806 , respectively, and the $P$ value was 0.001 , all of which passed the significance test of $1 \%$, indicating that there was a significant spatial correlation between the supply and demand of water in 

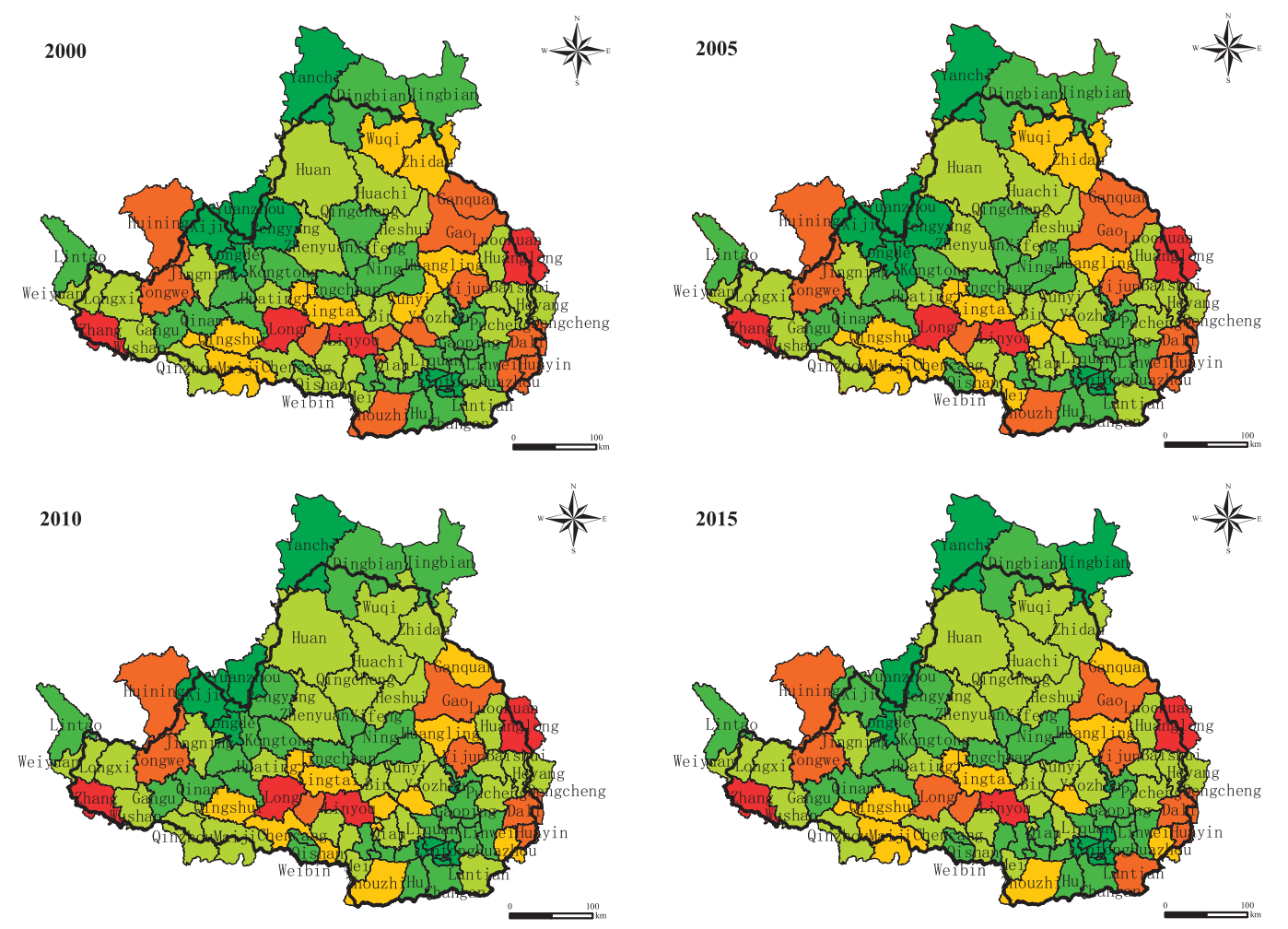

\section{Legend}
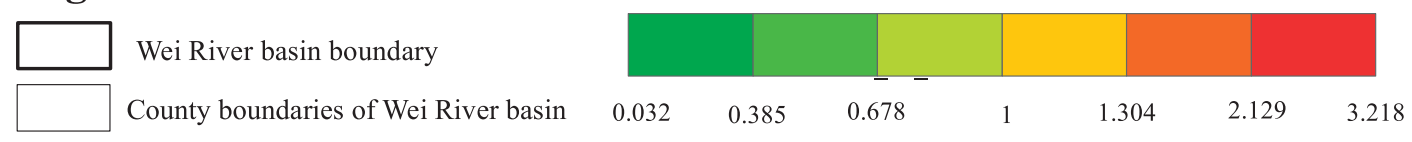

Fig. 8. Supply-demand ratio of water yield service in Wei River Basin.

Wei River basin. It was noteworthy that Moran's I rose slowly, which indicated that the spatial agglomeration effect of supply and demand of water in Wei River basin from 2000 to 2015 presented a slightly growth trend.

Based on the bivariate local correlation analysis of supply and demand of water yield service in Wei River basin, it was identified that there were three types of spatial matching of high-high type (high supply and high demand) spatial matching, low-low type (low supply and low demand) spatial matching and high-low type (high supply and low demand) spatial misplacement of water (Fig. 10). It was found that in Wei River basin, low-low spatial matching was the dominant matching type of water yield service supply and demand, followed by high-high spatial matching and high-low spatial dislocation. From the perspective

Table 6. Local Moran's I in Wei River Basin.

\begin{tabular}{|c|c|c|c|c|}
\hline & 2000 & 2005 & 2010 & 2015 \\
\hline Moran's I & 0.427 & 0.444 & 0.459 & 0.466 \\
\hline Z value & 8.182 & 8.482 & 8.68 & 8.806 \\
\hline P value & 0.001 & 0.001 & 0.001 & 0.001 \\
\hline
\end{tabular}

of spatial distribution, the low-low spatial matching was mainly distributed in the middle-east and north of the Wei River basin (Yanchi County, Ningxia province). The percentage of county-level regions involved accounted for about $20.43 \%$ of the whole region (93 counties), mostly concentrated in northern Shaanxi and eastern Gansu province. The high-high spatial matching was mainly concentrated in Guanzhong $\mathrm{Xi}$ 'an area of Shaanxi province, involving 5 areas of Beilin, Yanta, Xincheng, Lianhu and Weiyang district. High-low spatial dislocation only involved Fengxiang County of Shaanxi province in the south of the region. From the perspective of time, the spatial matching of supply and demand of water yield service in Wei River basin did not change significantly during the study period. The spatial matching of water service supply and demand in Fengxiang County of Shaanxi province changed from the high-low spatial dislocation in 2000 to the low-low spatial matching in 2005, and then returned into the high-low spatial dislocation in 2010 and 2015. The main reasons were the change of regional precipitation and other climatic factors which led to the change of supply of water yield service. Meanwhile, the acceleration of urbanization process and population migration increased the demand of water resources significantly. 

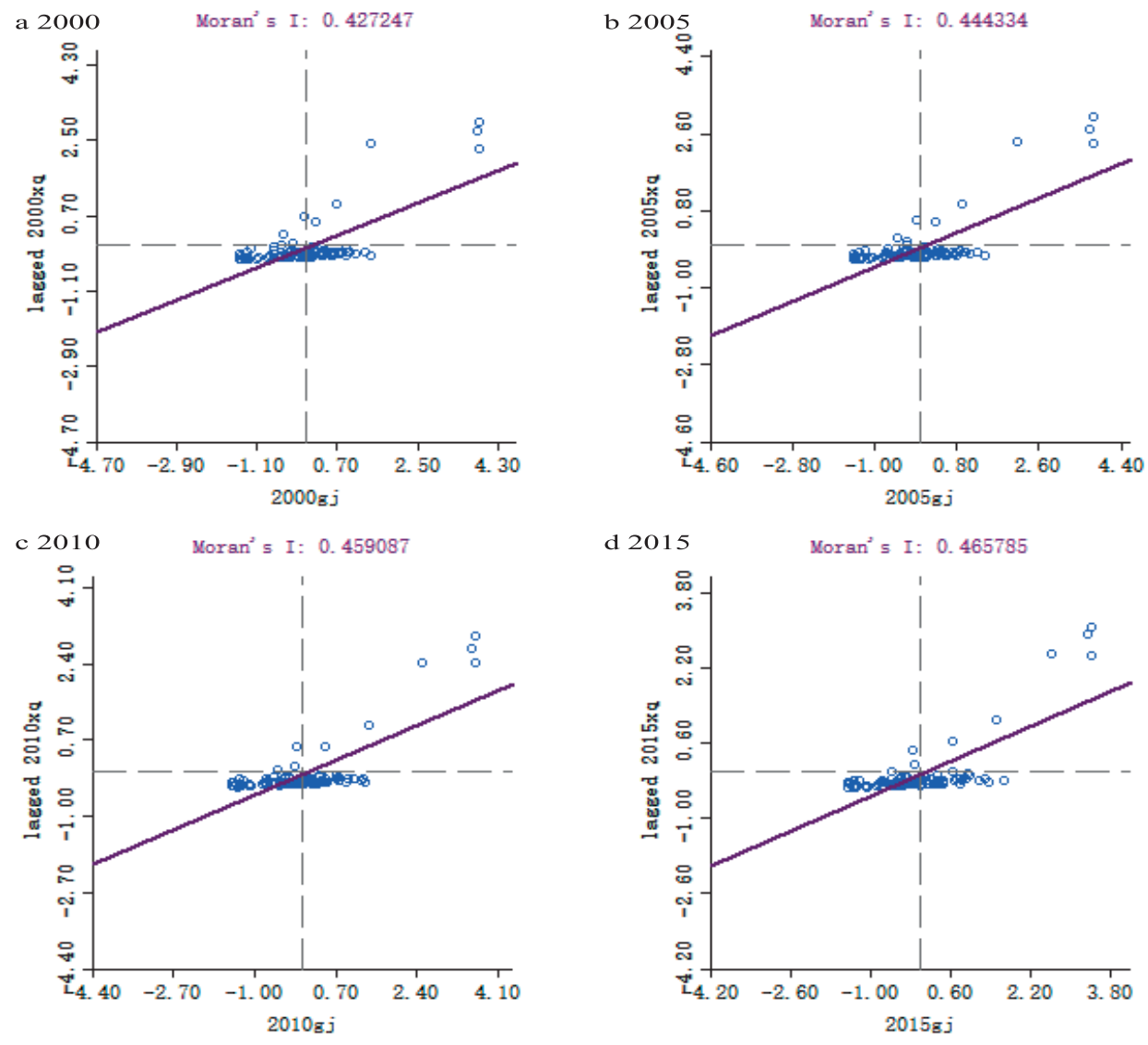

Fig. 9. Moran Index of Water Yield Service in Wei River Basin.
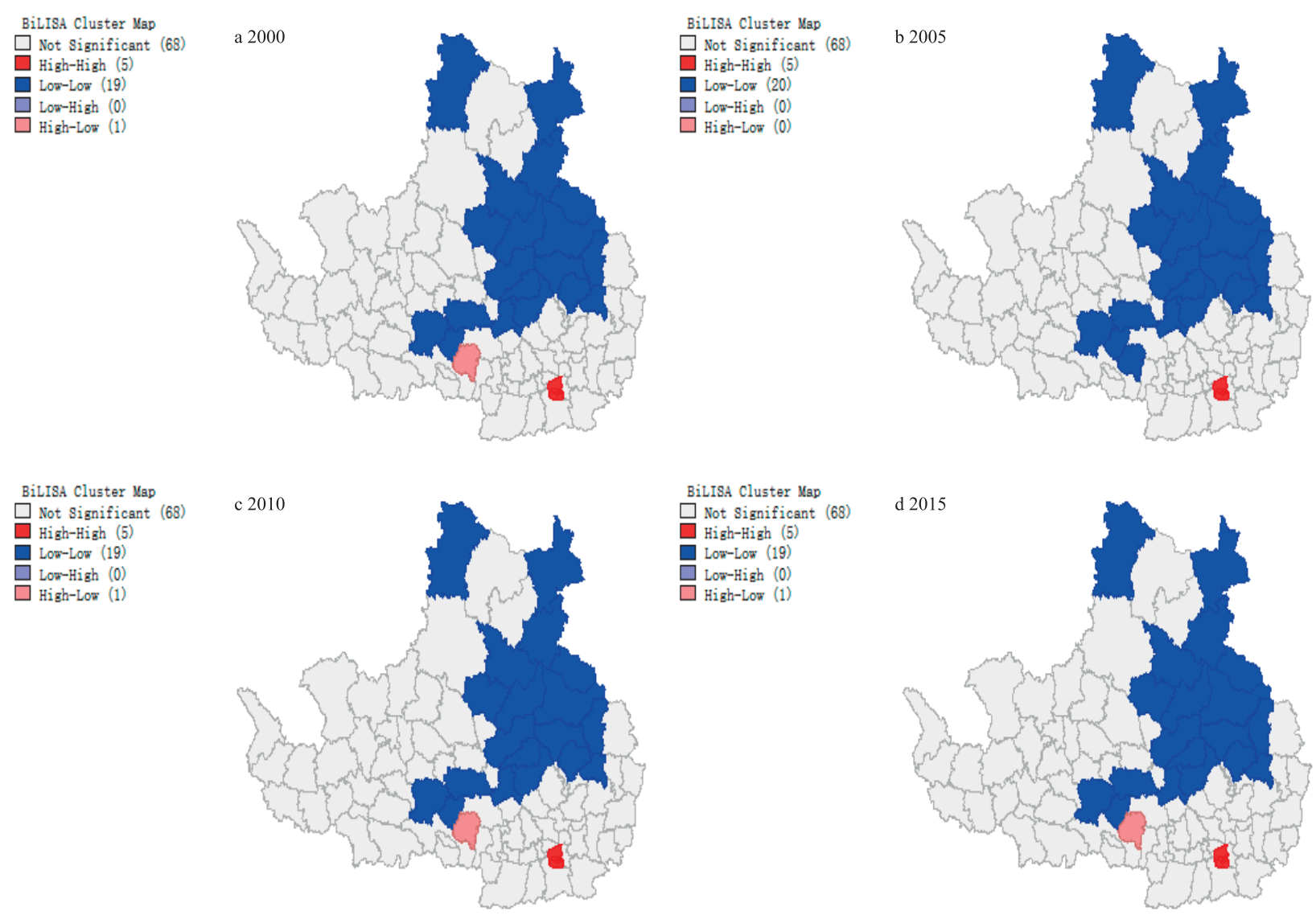

Fig. 10. Spatial matching of supply and demand of water yield service in Wei River Basin. 


\section{Discussion}

\section{Analysis of Influencing Factors of Water Yield Service in Wei River Basin}

Different land use types have different water yield. Varol $T$ et al. [39] evaluated the impact of different quantity of material collectors on soil compaction, which may further affect the supply of water yield service in the region. Our study found that the total amount of runoff and runoff per unit area of land use types in Wei River basin were different (Table 3). For the main land use types, the basic performance of water yield was farm land $>$ grass land $>$ forest, which was consistent with the results obtained by Wang Fei [38] in his study of Wei River basin. The main reason was that plants have good water conservation function. In the process of growth, plants need to consume a large amount of water. At the same time, plant branches and leaves had the effect of interception and transpiration on precipitation, which would extend the time of water yield to a certain extent and provide certain conditions for evaporation [38]. As a result, forest produced the least water, followed by grass land. From the perspective of time, the annual output of land use patterns in Wei River basin changed from 2000 to 2015 (Table 4). The water yield of farm land decreased, while that of forest and construction land increased. Water yield of grass land and unused land showed a fluctuating increase and decrease. Considering the local actual situation, the ecological environment of Wei River basin has been damaged to varying degrees due to the impact of human production activities. The state has carried out a series of ecological restoration projects and ecological protection policies to protect vegetation and trees, and the farm land area has been reduced to a certain extent. In addition, with the rapid development of social economy and the continuous expansion of urbanization, land use patterns have undergone significant changes. It is not difficult to find that the amount of water yield is directly related to land use [38].

\section{Analysis of Supply and Demand Causes of Water Yield Service}

The equilibrium of supply and demand of catchment water yield service is affected by many factors. Ucun Ozel $\mathrm{H}$ et al. [40, 41] found that the harmful heavy metals contained in the basin would affect water quality, and the concentration of heavy metals in the basin would change with different seasons, which would restrict the use of water resources to a certain extent and thus affect the demand of water. The distribution pattern of supply of water in Wei River basin was high in the south and was low in the north (Fig. 6), which was mainly affected by regional precipitation and evaporation. In the northern part of the basin, the average annual precipitation was relatively low and the evaporation was high. In addition, there were many forest and grass lands in the northeast part of the basin, and the plants needed to consume a lot of water during the growth process. The interception and transpiration of branches and leaves on the precipitation would eventually make the supply of water of the region decrease [15]. The demand of water presented a largearea stable state (Fig. 7). Two reasons were as follows: (1) Lintao County in Gansu province had a lot of irrigated lands (nearly 380,000 mu), and its agricultural water consumption was relatively high. (2) The water demand increased gradually with the development of local industry. The high demand of water in Yanta district was closely related to the population density and the rapid development of industrial economy. In 2015 , the amount of water yield supply in the southwest of Wei River basin decreased slightly compared with that in 2000, which was mainly affected by the implementation of local ecological restoration projects. The vegetation coverage and the transpiration both increased significantly because farm land in these areas was converted to the forest [38], resulting in the relative reduction of water supply in 2015. At the same time, the construction land increased in the south-eastern plain area of the basin because of the influence of urban expansion. Besides, the annual average precipitation was relatively high and the evaporation was relatively low. Therefore, the supply of water in 2015 increased slightly compared with that in 2000. On the other hand, there was a significant decrease in demand of water in Ningxia. It was mainly related to the reduction of the total water consumption in Ningxia during the study period. The per capita water consumption in Ningxia decreased from $1,574.55 \mathrm{~m}^{3}$ in 2000 to $1,053.89 \mathrm{~m}^{3}$ in 2015 , and consumption of water reduced by $20.66 \mathrm{~m}^{3}$.

\section{Discussion on Spatial Matching Factors of Supply and Demand of Water Yield Service}

There were three types of spatial matching of water supply and demand in Wei River basin: low-low spatial matching, high-high spatial matching and highlow spatial dislocation (Fig. 10). The low-low spatial matching was mainly distributed in the middle east and northern part of Wei River basin. Due to the influence of less rainfall, higher evaporation and vegetation cover, the area produced relatively less water. And consumption of water declined because of the dispersed population and the undeveloped industry. High-high spatial matching mainly involved five regions such as Weiyang district of $\mathrm{Xi}$ 'an due to the high average annual precipitation and low evaporation. In addition, $\mathrm{Xi}$ 'an, as the capital city of Shaanxi, has a high population density. With the economic development, the region consumed more water [15]. High-low spatial dislocation only involved Fengxiang County of Shaanxi province in the south of the study area. The supply of water was high and the demand of water was low affected by climatic and topographic factors. The spatial matching of water supply and demand in Wei River basin 
changed from the high-low spatial mismatch in 2000 to the low-low spatial mismatch in 2005 only in Fengxiang County, Shaanxi Province, but then returned into the high-low spatial mismatch again. The main reasons could be related to the implementation of ecological restoration projects and the dry climate conditions.

\section{Future Research Prospects}

In this study, the supply and demand of water in Wei River basin were analyzed and discussed from the quantity and space. However, there are still the following deficiencies: (1) This paper only studied the water yield service in Wei River basin, but the water yield service is only a part of the ecosystem services, which cannot fully reflect the internal mechanism and driving mechanism of the balance of supply and demand of ecosystem services, and the balance of supply and demand of ecosystem services in Wei River basin has not been comprehensively evaluated. (2) In this paper, the spatial correlation between supply and demand of water in Wei River basin was analyzed on a county scale with a large range, which may have a certain degree of uncertainty impact on the evaluation results of spatial distribution of supply and demand of water in the region. Therefore, future research work can tend to focus on the following aspects: (1) The multi-dimensional and multi-time analysis of ecosystem services can be carried out comprehensively, then the coupling mechanism between the demand of ecosystem services and the multi-party stakeholders and other driving factors of the balance between supply and demand of ecosystem services can be studied. (2) Water quality factors can be taken into comprehensive consideration to study the spatial matching of regional supply and demand of water in a more refined grid scale, so as to put forward more meaningful decisions for specific county units and present the matching status of regional supply and demand of water in a more reasonable and accurate way. (3) Ecological compensation can be integrated, and the watershed ecological compensation standard can be analyzed and studied from the perspective of supply and demand. Finally, our study should explore the application mode of supply and demand of ecosystem services from theory to practice, so as to provide a more reasonable and feasible scientific basis to the efficient utilization, the rational allocation of natural resources, the regulation and management of ecosystem services and the sustainable development of social economy.

\section{Conclusions}

In this study, the spatial analysis tools of InVEST model, ArcGIS and GeoDa were used to analyse and evaluate the supply-demand characteristics and the spatial matching of supply-demand of water yield service in Wei River basin, and our findings were as follows:

(1) The supply of water yield service was directly related to the way of land use. The total annual supply of water in Wei River basin in 2015 increased by 271 million $\mathrm{m}^{3}$ compared with that in 2000 , and the main water yield of land use type was farm land $>$ grass land $>$ water area $>$ forest. The water yield per unit area in different categories was also different: unused land $>$ construction land $>$ farm land $>$ grass land $>$ forest $>$ water area.

(2) The distribution pattern of supply of water in Wei River basin was high in the south and low in the north, and the demand of water was relatively stable. The total supply of water increased year by year, and the total demand first decreased and then increased. The annual supply and demand of water in Wei River basin had obvious spatial heterogeneity from 2000 to 2015 , which was mostly manifested as water yield service deficit (demand exceeds supply). However, with the advance of time and the development of social economy, the deficit of water yield service in counties (districts) decreased.

(3) There were three spatial matching types of supply and demand of water in Wei River basin. The portion of low-low spatial matching in Wei River basin was the largest, accounting for $20.43 \%$ of the whole region. The high-high spatial matching was mainly concentrated in $\mathrm{Xi}$ 'an of Guanzhong plain, Shaanxi province. The high-low spatial dislocation only involved Fengxiang county of Shaanxi province in the south of the study area.

As one of the important functions of ecosystem services, it has great practical significance to assess the supply and demand of water yield service. The evaluation method of this paper can provide a reference to the unbalanced supply and demand of regional water and its spatial matching, so as to realize the rational and effective allocation of water resources and ensure the high-quality and sustainable development of regional ecological and environmental protection. In order to control the soil erosion in Wei River basin and improve the rational allocation and efficient utilization of water resources, we offer the following suggestions. (1) Based on the area proportion of different land use types in the region and their contribution to runoff, the government should allocate land use structure reasonably in the future. At the same time, it is necessary to strengthen the protection of forest and grass land ecosystem to ensure ecological water use and to achieve the purpose of soil and water conservation finally. In addition, we need to pay more attention to the prevention and control of heavy metal pollution of the river basin. (2) Based on the distribution characteristics of unbalanced supply and demand of water and spatial matching of supply and demand, we can introduce advanced and efficient water-saving irrigation technology and strengthen the construction of water conservancy infrastructure. Our aim is to improve the spatial allocation and 
rational utilization of water resources in the future. In addition, an effective public supervision system should be established to improve the awareness of ecological protection in conserving water and maintaining the ecology, so as to realize the sustainable development of the ecology of the Yellow River.

\section{Acknowledgements}

The financial support of Special Fund for Scientific Research of Forestry Public Welfare Industry (No. 201504424) is gratefully acknowledged. The author would like to thank Shunbo Yao, Yuanjie Deng, Lei Jia, Mengyang Hou and Zhiwen Gong for improving the quality of this manuscript.

\section{Conflict of Interest}

The authors declare no conflict of interest.

\section{References}

1. DAILY GC. Nature's Services: Societal Dependence on Natural Ecosystems. Island Press, Washington DC, 1997.

2. COSTANZA R., DARGE R.C., DE GROOT R., FARBER,S., GRASSO M., HANNON B., LIMBURG K.E., NAEEM S., ONEILL R.V., PARUELO J.M., RASKIN R. SUTTON P.C., BELT M.V.D., PEARCE D. The value of the world's ecosystem services and natural capital. Nature, 387 (6630), 253, 1997.

3. LANG Y., SONG W., ZHANG Y. Responses of the wateryield ecosystem service to climate and land use change in Sancha River Basin, China. Physics and Chemistry of the Earth, 101, 102, 2017.

4. DAI E.F., WANG Y.H. Spatial heterogeneity and attribution analysis of water yield service in Hengduan Mountains. Journal of Geographical Sinica, 75 (03), 607, 2020.

5. SANCHEZCANALES M., BENITO A.L., PASSUELLO A.,TERRADO M., ZIV G. ACUNA V., SCHUHMACHER M., ELORZA F.J. Sensitivity analysis of ecosystem service valuation in a Mediterranean watershed. Science of the Total Environment, 440 (440), 140, 2012.

6. AHMED M.A., ABDELRAHMAN A., ESCOBEDO F.J., CROPPER W.P., MARTIN T.A., TIMILSINA N. Spatiallyexplicit modeling of multi-scale drivers of aboveground forest biomass and water yield in watersheds of the Southeastern United States. Journal of Environmental Management, 199, 158, 2017.

7. HE W., SONG G.J. Research on Performance Evaluation and Water Demand Estimation of Urban Water Resources Utilization in Hebei province. Journal of Scientiae Circumstantiae, 38 (07), 2909, 2018.

8. DOU P.F., ZUO S.Z., REN Y., DAI S.Q., YUN G.L. Impact of climate and land use / cover change on water production services of ecosystems in Ningbo. Journal of Environmental Sciences, 39 (07), 2398, 2019.

9. WANG B.S., CHEN H.X., DONG Z., ZHU W., QIU Q.Y. Impact of land use change on ecosystem water conservation services in the Fujian delta urban agglomeration in 2030. Journal of Ecological Sinica, 40 (02), 484, 2020.

10. BASTOLA S., SEONG Y.J., LEE S.H., JUNG Y.H. Water yield estimation of the Bagmati basin of Nepal using GIS based InVEST model. Journal of Korea Water Resources Association, 52 (9), 637, 2019.

11. HOU W.J., GAO J.B., DAI E.F., PENG T., WU S.H. Simulation of runoff services and spatial variability of the Wucha Sancha River ecosystem based on the SWAT model. Journal of Geographical Sinica, 73 (07), 1268, 2018.

12. YANG D., LIU W., TANG L.Y., CHEN L., LI X.Z., XU X.L. Estimation of water provision service for monsoon catchments of South China: Applicability of the InVEST model. Landscape and Urban Planning, 182, 133, 2019.

13. XU D.X., WU F., HE L.H., LIU H.X., JIANG Y. The impact of land use change on ecosystem services - Taking Zhangjiakou-Chengde area as an example. Journal of Ecological Sinica, 39 (20), 7493, 2019.

14. SINISCALCHI A.G., PRIETO C.G., GOMEZ E.A., RANIOLO A., LARA R.J., DIZA A.S. Ecosystem Services Valuation and Ecohydrological Management in Salt Lakes with Advanced Dynamic Optimisation Strategies[M]//Elsevier, 1579, 2019.

15. LIU L.C., LIU C.F., WANG C., LI P.J. Research on matching of supply and demand of ecosystem services in the Loess Hilly Region - Taking Lanzhou as an example. Journal of Geographical Sinica, 74 (09), 1921, 2019.

16. CONG W.C., SUN X.Y., GUO H.W., SHAN R.F. Comparison of the SWAT and InVEST models to determine hydrological ecosystem service spatial patterns, priorities and trade-offs in a complex basin. Ecological Indicators, 112, 106089, 2020.

17. LIU J.Y., NING J., KUANG W.H., XU X.L., ZHANG S.W., YAN C.Z., LI R.D., WU S.X., HU Y.F., DU G.M.,CHI W.F., PAN T., NING J. Temporal and spatial patterns and new features of land use change in China from 2010 to 2015. Journal of Geographical Sinica, 73 (05), 789, 2018.

18. LIU J.Y., KUANG W.H., ZHANG Z.X., XU X.L., QIN Y.W., NING J., ZHOU W.C., ZHANG S.W., LI R.D., YAN C.Z.,WU S.X., SHI X.Z., JIANG N., YU D.S., PAN X.Z., CHI W.F. Basic characteristics and spatial pattern of land use change in China since the late 1980s.Journal of Geographical Sinica, 69 (01), 3, 2014.

19. LIU J.Y., ZHANG Z.X., XU X.L., KUANG W.H., ZHOU W.C., ZHANG S.W.,LI R.D., YAN C.Z., YU D.S., WU S.X., JIANG N. Analysis of the spatial pattern and driving forces of land use change in China in the early $21^{\text {st }}$ century. Journal of Geographical Sinica, 64 (12), 1411, 2009.

20. LIU J.Y. China Resources and Environment Remote Sensing Macroscopic Survey and Dynamic Research. Beijing: China Science and Technology Press, 1996.

21. HAMON W.R. Estimating potential evaporation. Massachusetts Institute of Technology, 1960.

22. ZHOU W.Z., LIU G.H., PAN J.J. Distribution of soil effective water content in China (English). Journal of Geographical Sciences, 01, 5, 2005.

23. ZHANG B. Evaluation of water conservation function of artificial irrigated grass system in hilly area of Loess Plateau. Lanzhou University, 2019.

24. BAO Y.B., LI T., LIU H., MA T., WANG H.X., LIU K., SHEN Q., LIU X.H. Temporal and spatial changes of water conservation functions in the Loess Plateau in northern Shaanxi based on InVEST model. Geographical Research, 35 (04), 664, 2016. 
25. YU Y.T. Eco-rehabilitation zoning and vegetation optimal allocation for the water conservation function in the Hanjiang River basin. Nanjing University of Information Science and Technology, 2018.

26. BHAGABATI N., RICKETTS T.H., BARANO T., SULISTYAWAN S., CONTE M., ENNAANAY D., HADIAN O., MCKENZIE E., OLWERO N., ROSENTHAL A., TALLIS H., WOLNY S. Ecosystem services reinforce Sumatran tiger conservation in land use plans. Biological Conservation1, 69 (387), 147, 2014.

27. LEH M., MATLOCK M.D., CUMMINGS E., NALLEY L. Quantifying and mapping multiple ecosystem services change in West Africa. Agriculture Ecosystems \& Environment, 165 (1751), 6, 2013.

28. NELSON E., MENDOZA G., REGETZ J., POLASKY S., TALLIS H., CAMERON D., CHAN K.M.A., DAILY G.C., GOLDSTEIN J., KAREIVA P., LONSDORF E.V., NAIDOO R., RICKETTS T.H., SHAW M. Modeling multiple ecosystem services, biodiversity conservation, commodity production, and tradeoffs at landscape scales. Frontiers in Ecology \& the Environment, 7 (1), 4, 2009.

29. LIAN M.A., ZHE W.U. The research progress of InVEST model. Ecological Economy, 31 (10), 126, 2015.

30. MARLATT W.E., BUDYKO M.I., MILLER D.H. Climate and life. Journal of Range Management, 28 (2), 160, 1975.

31. FU B.P. On the calculation of land surface evaporation. Chinese Journal of Atmospheric Sciences, (01), 23,1981.

32. ZHANG L., HICKEL K., DAWES W., CHIEW F.H.S. WESTERN A.W., BRIGGS P.R. A rational function approach for estimating mean annual evaporation. Water resources research, 40 (2), 2004.
33. DONOHUE R.J., RODERICK M.L., MCVICAR T.R. Roots, storms and soil pores: Incorporating key ecohydrological processes into Budyko's hydrological mode. Journal of Hydrology, 436, 35, 2012.

34. WANG Y.L. Study on the supply and demand of ecosystem services based on urban-rural gradient. Shanxi University, 2019.

35. MA X.Y., PEI T. Exploratory spatial data analysis of regional economic disparities in Bejing during 2001-2007. Progress in Geography, 29 (12), 1561, 2010.

36. WARTENBERG D. Multivariate spatial correlation: a method for exploratory geographical analysis. Geographical Analysis, 17 (4), 263, 1985.

37. WU X.D. WANG S., FU B., LIU Y.,ZHU Y. Land use optimization based on ecosystem service assessment: a case study in the Yanhe watershed. Land Use Policy, 72 (72), 303, 2018.

38. WANG F. Research on Wei River Basin Runoff and Ecosystem Service Value Based on Land Use Change. Northwest A \& F University, 2013.

39. VAROL T., EMIR T., AKGUL M., OZEL H.B., ACAR H.H., CETIN M. Impacts of Small-Scale Mechanized Logging Equipment on Soil Compaction in Forests. Journal of Soil Science and Plant Nutrition. 2020.

40. UCUN OZEL H., GEMICI B.T., GEMICI E., OZEL H.B., CETIN M., SEVIK H. Application of artificial neural networks to predict the heavy metal contamination in the Bartin River. Environ Sci Pollut Res, 2020.

41. UCUN OZEL H., OZEL H.B., CETIN M., SEVIK H., GENICI B.T., VAROL T. Base alteration of some heavy metal concentrations on local and seasonal in Bartin River. Environmental Monitoring and Assessment (Environ Monit Assess), 191, 594, 2019. 
